Eduvest - Journal of Universal Studies

Volume 1 Number 12, December 2021

p- ISSN 2775-3735 e-ISSN 2775-3727

\title{
ACCOUNTING INFORMATION SYSTEMS FOR FINANCIAL MANAGEMENT IN RELIGIOUS NON-PROFIT ORGANIZATIONS OF THE CHURCH
}

\section{Sarlin Paleina Nawa Pau, Maria Prudensiana Leda Muga, Yemima Eka Christi Windya, Melianus Efritron Tkela}

Nusa Cendana University, Indonesia

E-mail: sarlin.pau@staf.undana.ac.id, maria.muga@staf.undana.ac.id, mimawindya89@gmail.com, jongfridz@gmail.com

\begin{tabular}{ll}
\hline ARTICLE INFO & ABSTRACT \\
\hline Received: & The church is a non-profit religious institution. Good \\
November, 26th & financial management of church religious institutions is \\
2021 & needed to improve the quality of service to the \\
Revised: & congregation. One form of church financial management \\
December, 17th & is to manage financial information in a good accounting \\
2021 & information system as a form of church responsibility or \\
Approved: & accountability in managing the congregation's money. \\
December, 19th & $\begin{array}{l}\text { This research was conducted using a qualitative } \\
2021\end{array}$ \\
& $\begin{array}{l}\text { descriptive research method. The type of data source used } \\
\text { in this study is qualitative data. Sources of data in this } \\
\text { study are primary data and secondary data. The data in } \\
\text { this study are primary data and secondary data. The data } \\
\text { collection technique in this research is through field } \\
\text { studies and literature studies. The results of this study are } \\
\text { the accounting information system in the context of } \\
\text { managing church finances at the Evangelical Masehi } \\
\text { Church in Timor Jemaat Kota Baru Klasis Kupang City is } \\
\text { cash receipts and disbursements that carry out financial } \\
\text { reporting every week on congregation news, monthly } \\
\text { financial reports and conduct congregational } \\
\text { congregations to report servants and finances every year. }\end{array}$ \\
\hline
\end{tabular}

Sarlin Paleina Nawa Pau, Maria Prudensiana Leda Muga, Yemima Eka Christi Windya, Melianus Efritron Tkela (2021). Accounting Information Systems for Financial Management in Religious Non-Profit

Organizations of the Church. Journal Eduvest. 1(12): 1544-1555

How to cite:

E-ISSN:

Published by: https://greenpublisher.id/ 


\begin{tabular}{ll}
\hline & $\begin{array}{l}\text { The procedure is still carried out using a computer but still } \\
\text { manually. This research then creates an accounting } \\
\text { information system for cash receipts and disbursements. }\end{array}$ \\
\hline KEYWORDS & $\begin{array}{l}\text { Accounting Information System, Church, Financial } \\
\text { Management }\end{array}$ \\
\hline Cc) (i) (O) & $\begin{array}{l}\text { This work is licensed under a Creative Commons } \\
\text { Attribution-ShareAlike 4.0 International }\end{array}$ \\
\hline
\end{tabular}

\section{INTRODUCTION}

The current development of society's need for information about various things has become a necessary thing for knowledge, as a form of responsibility or as decision making based on available information. A franchise organization that is for-profit or a non-profit organization that is not for-profit requires a good information system to be able to provide the required information (Svensson \& Wood, 2011). This information is needed for the continuity of the organization in making decisions to achieve organizational goals and as a form of maintaining the trust of members or stakeholders (Lakos \& Phipps, 2004).

Good information is information that is timely, useful and reliable. One of the important information systems in the organization is the accounting information system (Kabuhung, 2013). Accounting is the process of recording, classifying and processing financial transactions to become information needed in decision making for both internal and external parties (Young, 2006). Information that is important for decision making requires a system that is used to support operational activities for managing information and reports (Marlina \& Iskandar, 2019).

The church is a non-profit religious institution. The church has a primary orientation to serve its congregation. However, good financial management is needed for religious organizations to improve the quality of service to the congregation (Coştu et al., 2017). According to PSAK number 45, the financial statements of non-profit entities are to provide relevant information to meet the interests of resource providers who do not expect repayment, members, creditors and other parties who provide resources for nonprofits (Nurjannah, 2018). One form of church nonprofit organization at least needs to create an accounting information system for cash receipts and disbursements (Marlina \& Sudana, 2020).

Many problems that are often faced by the church are related to the management of church finances (West \& Zech, 2007). Funds in church organizations are often considered as social funds that need to be used up in ministry so that in financial management it seems that they do not pay too much attention to the use of church money which can lead to misuse (Nitterhouse, 1997). Church finances are misused in their allocation due to a lack of good financial management (Rixon, Rois, \& Faseruk, 2014).. One form of church financial management is to manage financial information in a good accounting information system as a form of church responsibility or accountability in managing the congregation's money (sudana \& Marlina, 2019).

Based on this phenomenon, the researcher is interested in examining how the financial accounting information system occurs in the GMIT Kota Baru Klasis church, Kupang City.

\section{RESEARCH METHOD}


The research was conducted using descriptive qualitative research methods regarding Accounting Information Systems for Financial Management in Church Religious Non-Profit Organizations. Qualitative descriptive research method is a research that is intended to reveal an empirical fact objectively scientifically based on scientific logic, procedures and supported by strong methodologies and theories in accordance with the disciplines being occupied (Muktar, 2020). This study uses primary data and secondary data, namely: Primary data obtained from field activities through interviews and observations of related parties, such as church administrators or church congregations. Secondary data is data obtained from materials available in books and other sources from the Evangelical Christian Church in Timor Kota Baru Klasis, Kupang City, which is related to this research.

Researchers collected data from ongoing activities at the Evangelical Christian Church in Timor Kota Baru Klasis, Kupang City, East Nusa Tenggara. Collecting data on research through empirical data collection conducted through field studies and literature studies.

The analysis technique used in this study is as follows:

1. Study and understand the organizational structure of the Evangelical Christian Church in Timor Kota Baru Klasis, Kupang City and the duties and responsibilities of each.

2. Studying the series of financial activities that exist in the Evangelical Christian Church in Timor Kota Baru Klasis, Kupang City through interviews and documents

3. Collecting forms or documents related to financial activities at the Evangelical Christian Church in Timor Kota Baru Klasis Kota Kupang

4. Conduct an analysis of the practice of financial activities at the Evangelical Christian Church in Timor Kota Baru Klasis, Kupang City by looking at the accounting information system applied by analyzing:

5. Implement an accounting information system that can be used at the Evangelical Christian Church in Timor Kota Baru Klasis, Kupang City.

a. Define operational procedures

b. Create a financial reporting flow format.

\section{RESULT AND DISCUSSION}

\section{Overview of Research Objects}

The Evangelical Christian Church in Timor (GMIT) Kota Baru Klasis Kota Kupang is one of the churches which officially opened its services on January 15, 1989, which later became the birthday of the GMIT Kota Baru congregation, which is theologically in line with the true existence of the church. The residents who moved came from the service area of GMIT Paulus Naikoten and GMIT Kupang City who needed a closer place of worship. GMIT Synod Assembly Decision Letter No. 176A/II.2/1989 on July 6, 1989 established the new City of GMIT as a GMIT Member Church.

To carry out the five church service programs in accordance with the GMIT ministry master plan, the Daily Congregation Council, BPP and UPP and teachers have been formed with their respective job descriptions. Personnel Management as part of the office secretariat task which functions as the task of managing and supervising the existing service component system. The presence of personnel, namely the Pastor, the Congregational Council, BP3J, BP4J, the Physical Development Committee, and the 


\section{Sarlin Paleina Nawa Pau, Maria Prudensiana Leda Muga, Yemima Eka Christi Windya, Melianus Efritron Tkela}

Secretariat Service Unit. The routine service programs carried out by GMIT Kota Baru are public worship services, Sacramental Services, Marriage Blessings, Burial of the Dead, Services for Worship in the District, Categoial/functional Worship Services, Thanksgiving Services, Visiting Servants, and Holiday Services ecclesiastical.

\section{Results and Discussion}

Accounting Information System on the finances of the GMIT Kota Baru Church, namely cash receipts and disbursements that carry out financial reporting every week on church news, monthly financial reports and conduct congregations to report on servants and finances every year. The procedure is still carried out using a computer but still manually. The finance department or treasurer every week will record any cash receipts or income or offerings and cash disbursements or expenditures for routine activities and program activities.

The source of cash receipts for the classic GMIT Kota Baru congregation in Kupang comes from Routine Income which consists of Main Service offerings, holiday worship offerings, worship offerings, categorical/functional worship offerings, special offerings, votive offerings, tithing offerings, in-kind offerings, income UPP (Service Auxiliary Unit)/Category business, other income and income for development.

The cash expenditures of the GMIT Kota Baru congregation consist of routine expenditures and program expenditures and expenditures for development. Routine expenditures come from personnel expenditures, office expenses, transport expenses, diakonia expenses, congregation expenses, ecclesiastical holidays, and other expenses. Meanwhile, program expenditures come from UPP expenditures and expenditures for service support agencies. The New City GMIT Congregation's Cash Reserves are also in several bank accounts.

The accounting information system for cash receipts and cash disbursements procedures implemented by the GMIT Kota Baru congregation has been implemented effectively. The analysis procedure is as follows:

1. Analysis of Cash Receipt Procedures

The money for offerings from the main service, ecclesiastical holiday services, special offerings, votive offerings, and tithing offerings given by members of the congregation is given through the offering bag or offering box at the church, then each offering that is given will be calculated by the congregation in charge of the church. The service is then given to the church treasurer. then the church treasurer records in the church cash book for each reception on the date of the service according to the type of offering made. After being recorded in the cash book, then the treasurer recapitulates each cash receipt or cash income to be reported on the church's financial statements every week in the congregation's report written in every Sunday service. From the report every week then a report is made every month and every semester which will be accounted for at the time of the congregational assembly. As for offerings from worship services, offerings from categorical worship, UPP business income and other offerings given by the congregation at these services, then any offerings given will usually be under the supervision of the congregation on duty at that time or through the treasurer at the church. each area or neighborhood to then be given to the church treasurer. Then the church treasurer will record in the church cash book to be reported on the weekly financial statements of the congregation written in every Sunday service. The natura income is an in-kind offering of the congregation given by the congregation which will then be cashed out by other congregations through an auction and will be given to the church treasurer. In this church's income or cash receipts, there are revenues for church construction which are reported separately. This development offering is a specifically given by the 
congregation for church building.

2. Analysis of Cash Disbursement Procedures

Any church activity that requires church funding can go directly to the church treasurer. The church at the beginning of each fiscal year will determine the APBJ or the congregation's revenue and expenditure budget during that fiscal year. Each category or service support units and Rayons will include the program and funding needs needed for one year that will support the implementation of the five church service programs in accordance with the GMIT ministry master plan. The cash out will be based on the APBJ in accordance with the program of each service support unit, holiday activities, routine church operational expenses, and programs for service support agencies. Cash disbursements are based on routine expenditures and the program will be disposed of by the Chairperson of the Congregational Council.

After analyzing the procedures carried out by the GMIT Kota Baru Klasis Congregation in Kupang City in managing each cash receipt and disbursement, it can be seen that although the cash receipts and cash disbursements accounting information system applied is still manual, in general it has been carried out adequately.

\section{Financial Accounting Information System Cash Receipts and Cash Disbursements}

Based on the results of interviews and observations made by the researcher, a financial accounting information system for cash receipts and disbursements was created that can be used by the GMIT Kota Baru classic church in Kupang.

\section{Church Accounting Information System Context Diagram}

Context diagram is a diagram that describes the scope of the system. Context diagram is the highest level of DFD (Data Flow Diagram) which describes the whole system.

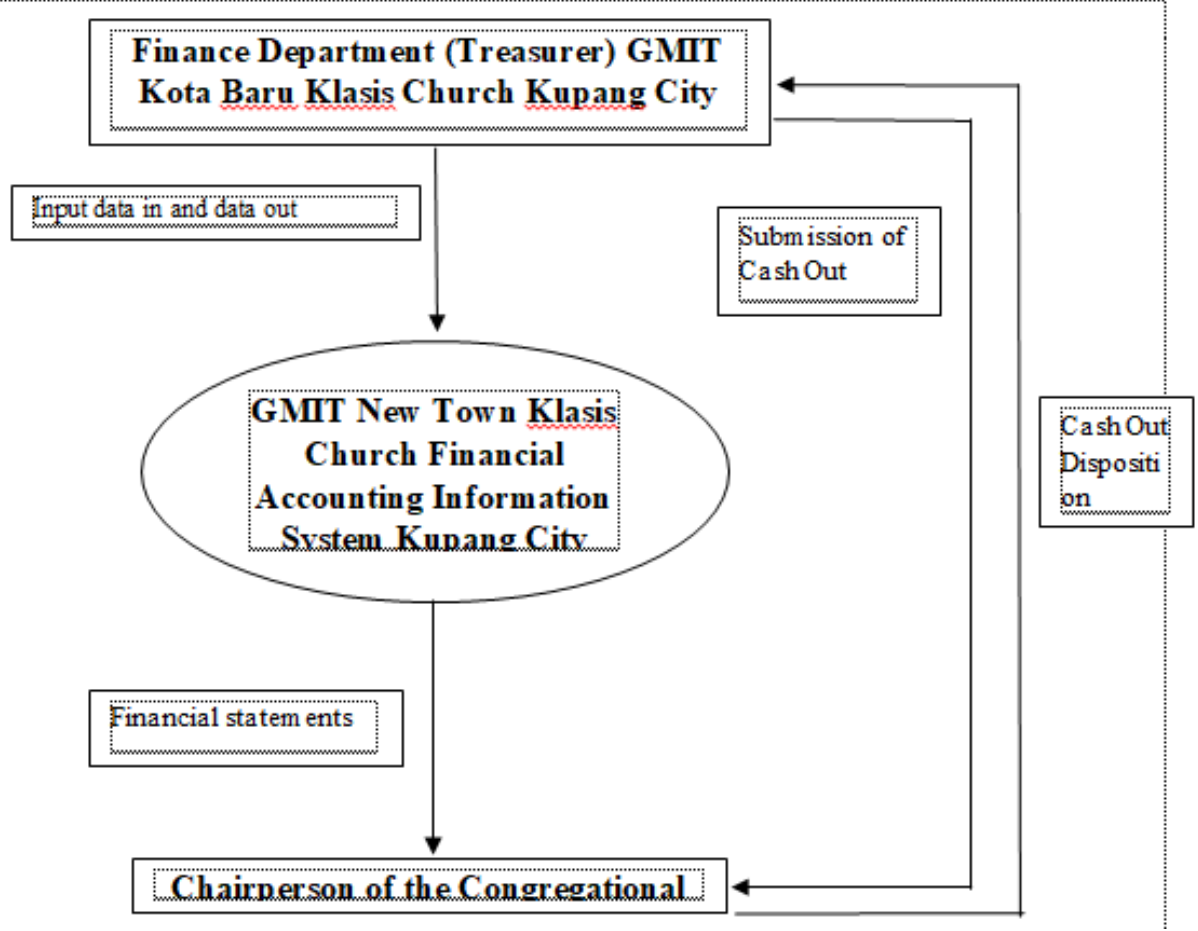

Figure 1 Context Diagram of Financial Accounting Information System on Cash Receipts and Disbursements

Source: Data processed by researchers 


\section{Sarlin Paleina Nawa Pau, Maria Prudensiana Leda Muga, Yemima Eka Christi Windya, Melianus Efritron Tkela}

\section{Data Flow Diagram (DFD) Financial Accounting Information System Church Cash Receipts}

The data flow diagram (DFD) of the accounting information system on cash receipts for the GMIT Kota Baru Klasis Church in Kupang City consists of the cash input process, making and updating, as well as the process of making financial reports. The finance department of the GMIT Kota Baru Klasis Church in Kupang City entered the transaction data for cash receipts that occurred. The cash receipt transaction data are reconciled based on evidence. The results of the cash receipts report are then given to the chairman of the church assembly (pastor) as shown in Figure 2.

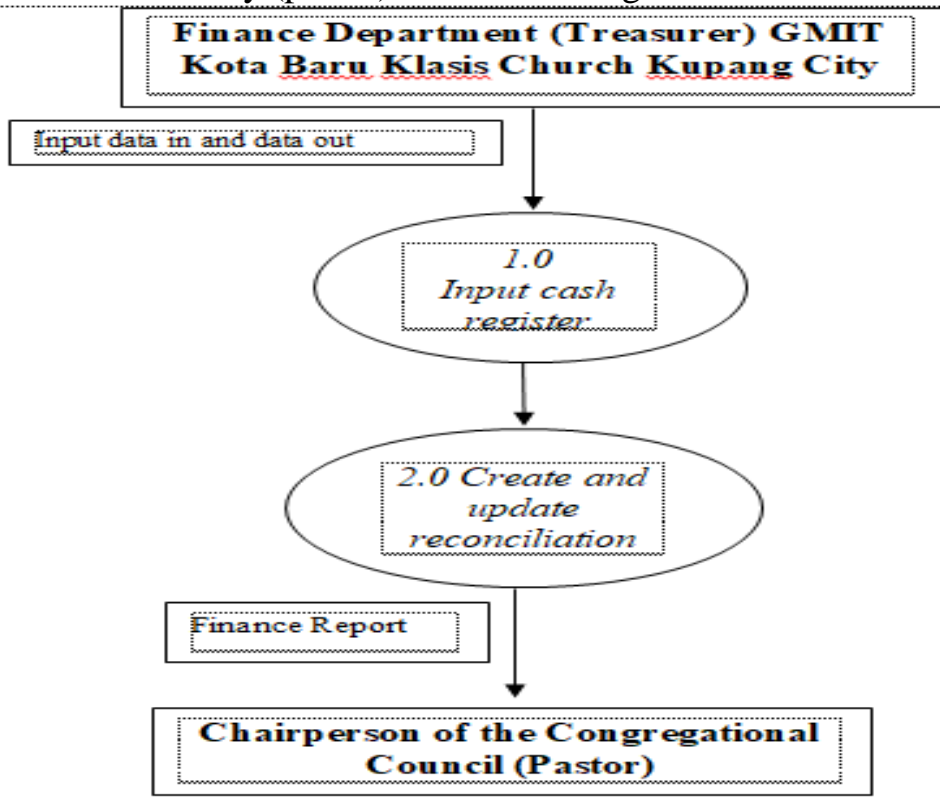

Figure 2 Data Flow Diagram of Financial Accounting Information System on Church Cash Receipts

Source: Data processed by researchers

Data Flow Diagram (DFD) Financial Accounting Information System Church Cash Expenditure

Data Flow Diagram (DFD) financial information system on cash disbursements of the GMIT Kota Baru Klasis Church Kupang City consists of a process, namely input expenditure based on evidence and disposition of the Chair of the Congregational Council, making and updating, cash receipts reports are then given to the Chairperson of the congregation (pastor) like picture 3 . 


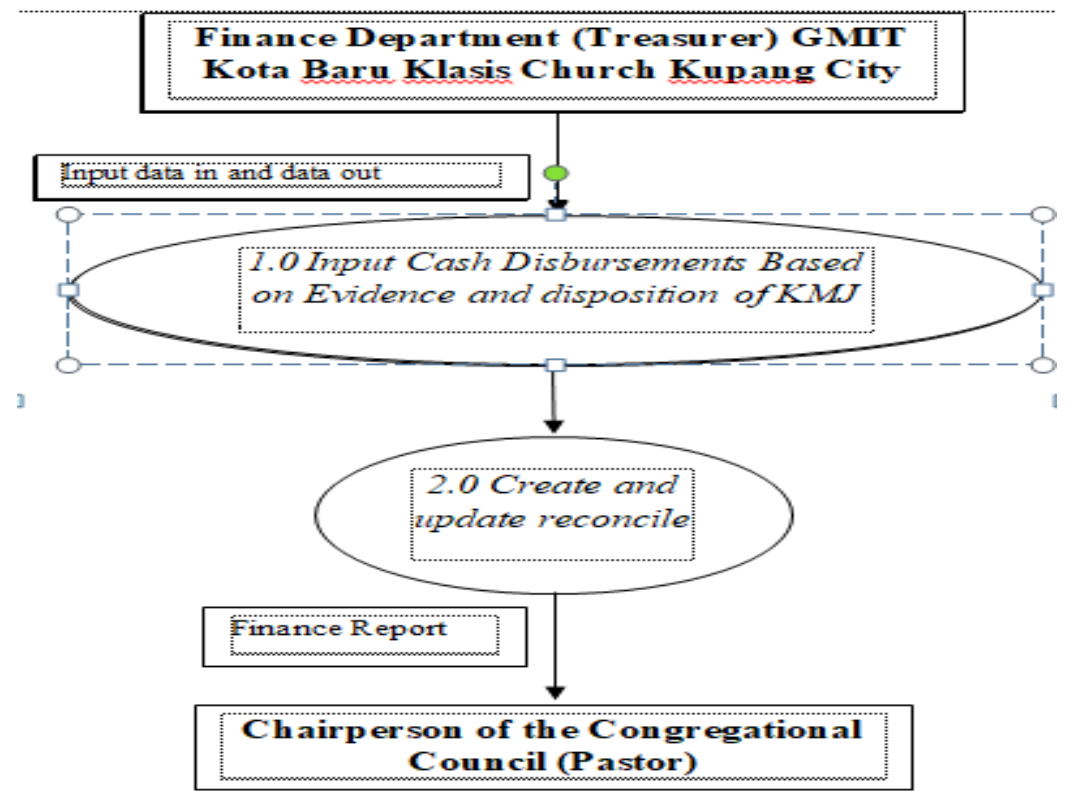

Figure 3 Data Flow Diagram of Financial Accounting Information Systems on Church Cash Expenditures

Source: Data processed by researchers

\section{Church Cash Receipt Financial Accounting Information System Flowchart}

The flowchart of the financial accounting information system for cash receipts at the GMIT Kota Baru Klasis Church in Kupang City is from the main service, ecclesiastical holiday services, special offerings, votive offerings, tithing offerings, worship offerings, offerings from categorical worship, UPP business income and other offerings .

This activity will start from a receipt report that is given to the church treasurer to record cash receipts based on the source, category and type of cash receipts (Finkler, Smith, \& Calabrese, 2018). The cash receipts will be deposited by the treasurer to the bank with a deposit slip from the church's financial statements that have been made and submitted and archived (Thornhill \& Madeline Ann Domino PhD, 2016). Financial reports archived by the Chief Pastor of the Congregational Council (KMJ). The deposit slip database can be inputted into the accounting information system so that the data can be stored neatly in the database and the financial reports generated by the accounting information system will be stored neatly so that the data becomes more secure. 


\section{Sarlin Paleina Nawa Pau, Maria Prudensiana Leda Muga, Yemima Eka Christi Windya, Melianus Efritron Tkela}

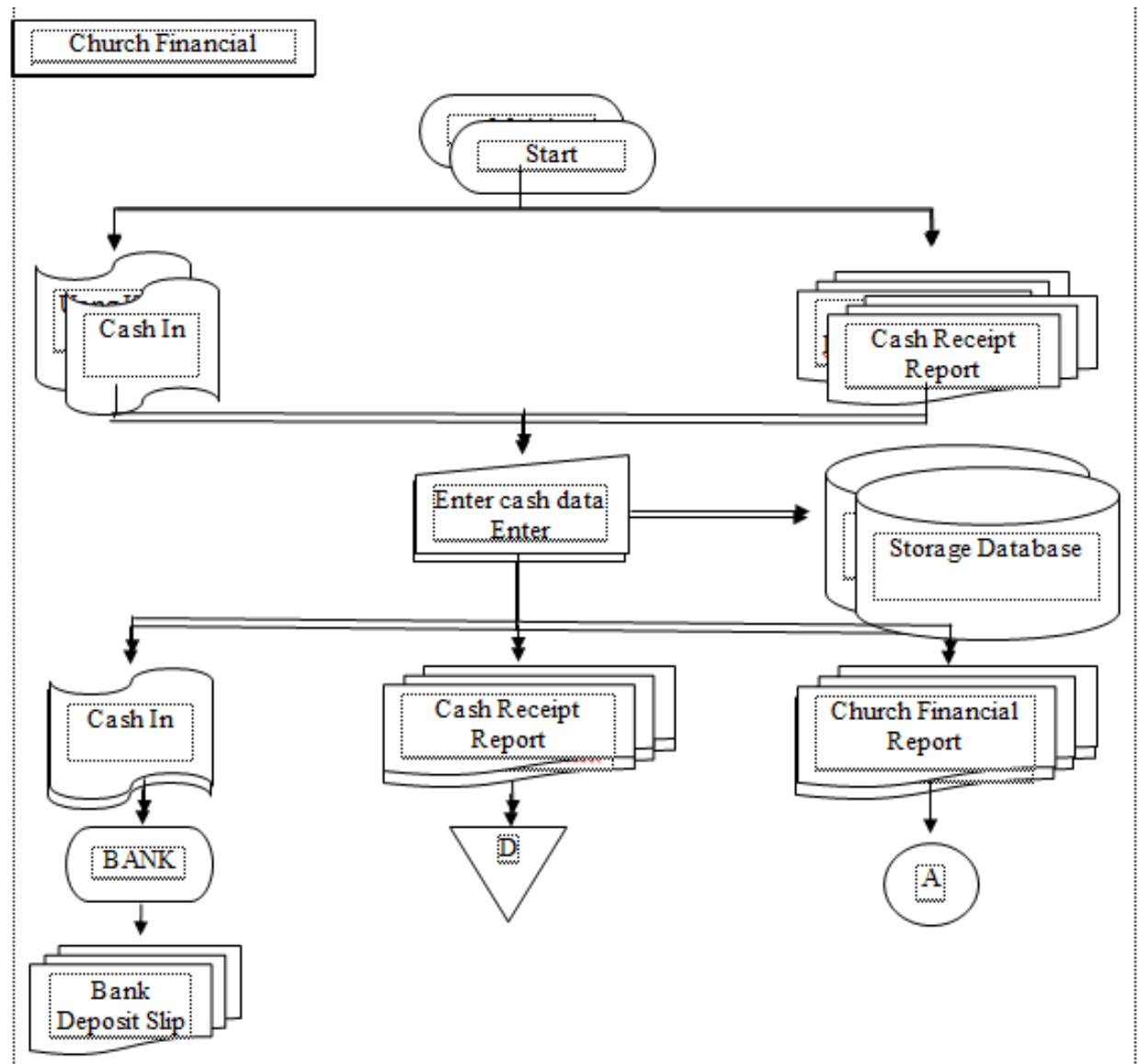

Figure 4 Flowchart of Financial Accounting Information System on Church Cash

Receipts

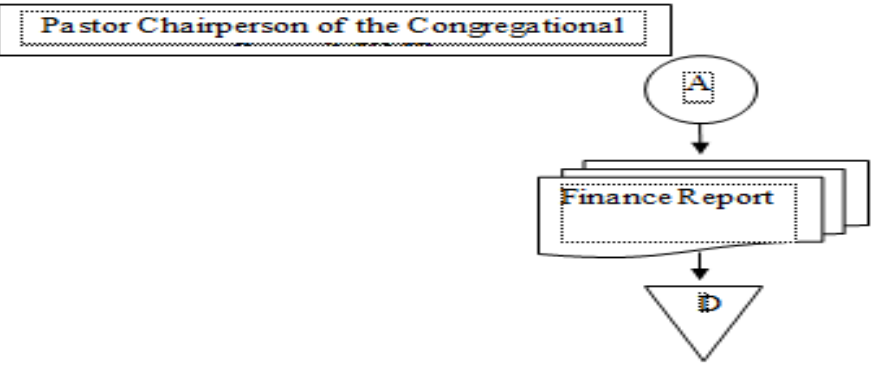

Church Cash Disbursements Financial Accounting Information System Flowchart

The flowchart of the financial accounting information system for cash receipts at the GMIT Kota Baru Klasis Church in Kupang City is from expenditures for service support unit programs, holiday activities, routine church operational expenses, and programs for service support agencies.

Church activities that require church funding can go directly to the church treasurer. The church at the beginning of each fiscal year will determine the APBJ or the congregation's revenue and expenditure budget during that fiscal year. Each category or service support units and Rayons will include the program and funding needs needed for one year that will support the implementation of the five church service programs in accordance with the GMIT ministry master plan. The cash out will be based on the APBJ in accordance with the program of each service support unit, holiday activities, routine church operational expenses, and programs for service support agencies. Cash disbursements are based on routine expenditures and the program will be disposed of by 
the Chairperson of the Congregational Council. The church treasurer will record the church's expenses based on the records and disposition of the KMJ and will provide proof of expenditure along with the money. Proof of cash disbursements can be inputted into the accounting information system so that the proof of expenditure data can be stored neatly in the database.

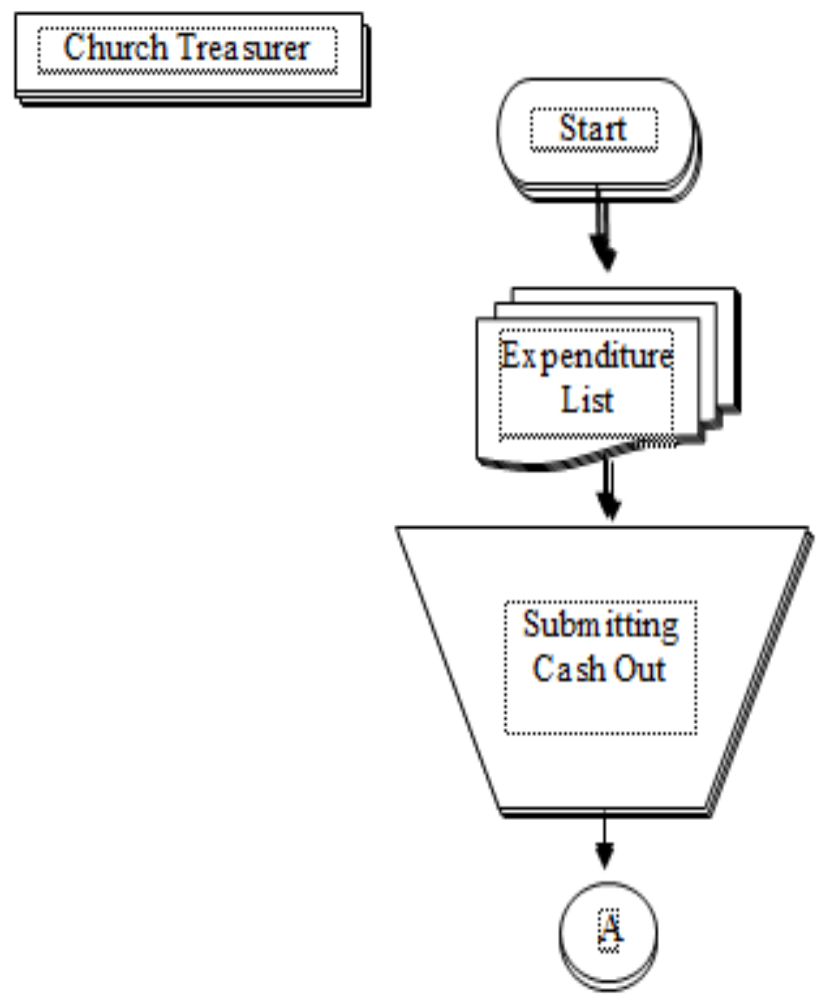


Sarlin Paleina Nawa Pau, Maria Prudensiana Leda Muga, Yemima Eka Christi Windya, Melianus Efritron Tkela

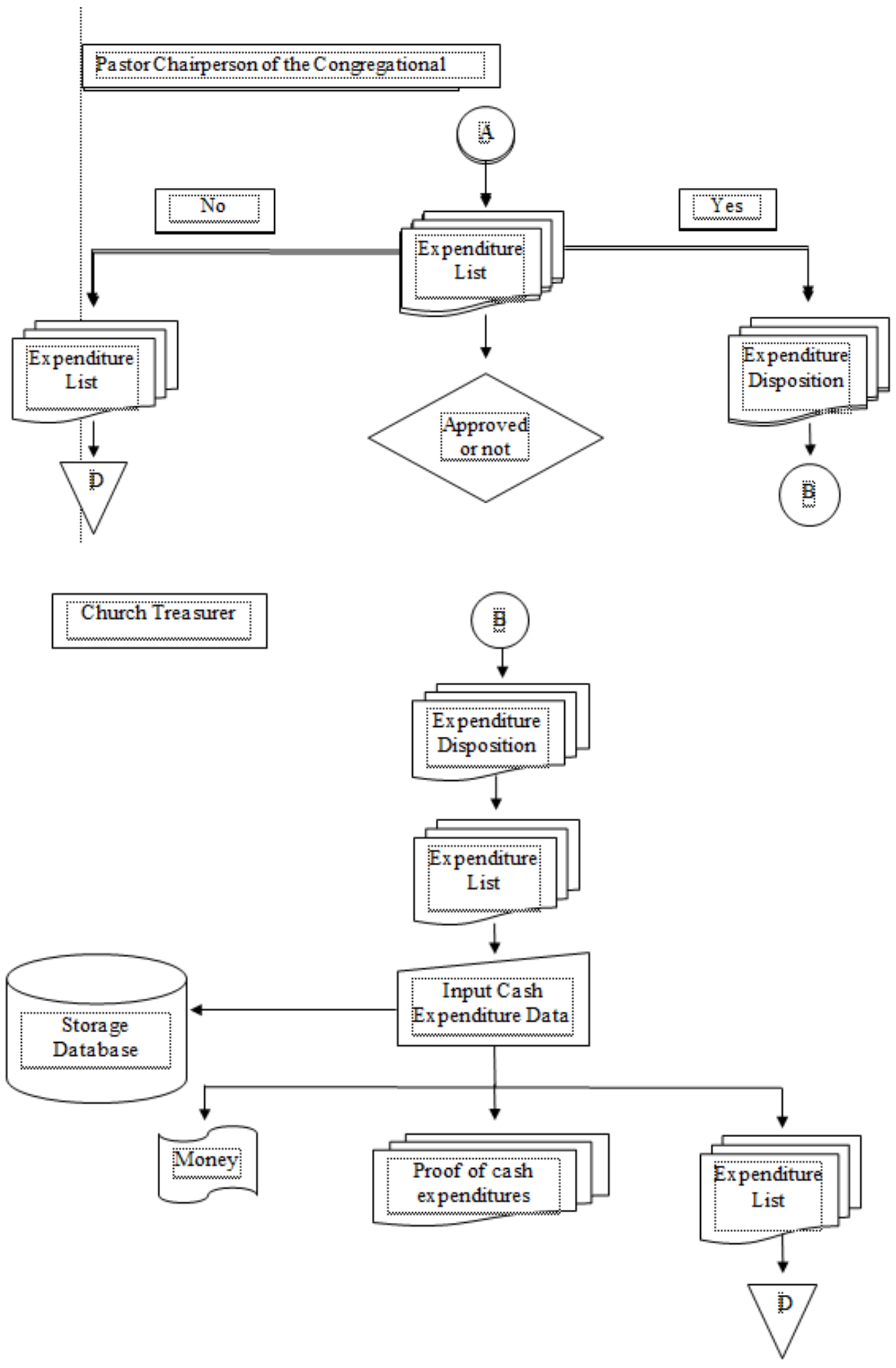




\section{CONCLUSION}

The results of this study conclude several things, as follows: Accounting Information System on the finances of the GMIT Kota Baru Church, namely cash receipts .and disbursements that carry out financial reporting every week on church news, monthly financial reports and conduct congregations to report on servants and finances every year. The procedure is still carried out using a computer but still manually. The finance department or treasurer every week will record any cash receipts or income or offerings and cash disbursements or expenditures for routine activities and program activities.

The source of cash receipts for the classic GMIT Kota Baru congregation in Kupang comes from Routine Income which consists of Main Service offerings, holiday worship offerings, worship offerings, categorical/functional worship offerings, special offerings, votive offerings, tithing offerings, in-kind offerings, income UPP (Service Auxiliary Unit)/Category business, other income and income for development.

The cash expenditures of the GMIT Kota Baru congregation consist of routine expenditures and program expenditures and expenditures for development. Routine expenditures come from personnel expenditures, office expenses, transport expenses, diakonia expenses, congregation expenses, ecclesiastical holidays, and other expenses. Meanwhile, program expenditures come from UPP expenditures and expenditures for service support agencies. The New City GMIT Congregation's Cash Reserves are also in several bank accounts.

\section{REFERENCES}

Coştu, Bayram, Hermıta, Neni, Suhandı, Andi, Syaodıh, Ernawulan, Samsudın, Achmad, Sopand1, Wahyu, Muslım, Muslim, Wibowo, Firmanul, Maftuh, Bunyamin, \& Prasetyo, Zuhdan. (2017). The Effectiveness of Using Virtual Simulation and Analogy in the Conceptual Change Oriented-Physics Learning on Direct Current Circuits. Coştu, Bayram, Hermıta, Neni, Suhandı, Andi, Syaodıh,... - Google Cendekia

Finkler, Steven A., Smith, Daniel L., \& Calabrese, Thad D. (2018). Financial management for public, health, and not-for-profit organizations. CQ Press.

Kabuhung, Merystika. (2013). Sistem informasi akuntansi penerimaan dan pengeluaran kas untuk perencanaan dan pengendalian keuangan pada Organisasi nirlaba keagamaan. Jurnal EMBA: Jurnal Riset Ekonomi, Manajemen, Bisnis Dan Akuntansi, 1(3).

Lakos, Amos, \& Phipps, Shelley E. (2004). Creating a culture of assessment: A catalyst for organizational change. Portal: Libraries and the Academy, 4(3), 345-361.

Marlina, Lina, \& Iskandar, Jajang. (2019). Pengaruh Bagi Hasil dan Pendapatan Per Kapita Terhadap Peningkatan Dana Pihak Ketiga. JURNAL EKONOMI SYARIAH, 4(1).

Marlina, Lina, \& Sudana. (2020). Does The Population Number, The Economic Growth, And The Inflation Influence The Growth Of Islamic Bank In Indonesia? DOI: http://dx.doi.org/10.31838/jcr.07.05.149. 7, 723-729.

Muktar, Muktar. (2020). Tinjauan Yuridis Potensi Pajak Restoran Terhadap Pendapatan Asli Daerah. Glosains: Jurnal Sains Global Indonesia, 1(1), 30-37.

Nitterhouse, Denise. (1997). Financial management and accountability in small, religiously affiliated nonprofit organizations. Nonprofit and Voluntary Sector Quarterly, 26(4_suppl), S101-S121. 


\section{Sarlin Paleina Nawa Pau, Maria Prudensiana Leda Muga, Yemima Eka Christi Windya, Melianus Efritron Tkela}

Nurjannah, Nurjannah. (2018). Akuntabilitas dan Pengelolaan Keuangan Masjid: PSAK No. 45 tentang Pelaporan Keuangan Organisasi Nirlaba. Universitas Islam Negeri Alauddin Makassar.

Rixon, Daphne, Rois, Judy, \& Faseruk, Alex. (2014). The seven deadly sins of church accounting. The Journal of Business Diversity, 14(1), 9.

sudana, \& Marlina, Lina. (2019). Pengaruh Kecukupan Modal Dan Efisiensi Operasional Terhadap Profitabilitas Pada Bank Cimb Niaga Syariah. 4, 157-170.

Svensson, Göran, \& Wood, Greg. (2011). A model of cause-related marketing for "profitdriven" and "non-profit" organizations. European Business Review.

Thornhill, Ryan, \& Madeline Ann Domino PhD, C. P. A. (2016). Passing the plate: A survey of internal controls in local churches. The Journal of Theoretical Accounting Research, 12(1), 25-53.

West, Robert, \& Zech, Charles. (2007). Internal financial controls in the US Catholic Church. Online: Http://Www. Villanova. Edu/Business/ Assets/Documents/ Excellence/Church/Catholicchurchfinances. Pdf.

Young, Joni J. (2006). Making up users. Accounting, Organizations and Society, 31(6), 579-600. 